\title{
HOW SHOULD MDG IMPLEMENTATION BE MEASURED: FASTER PROGRESS OR MEETING TARGETS?
}

\section{Sakiko Fukuda-Parr}

Graduate Program in International Affairs, New School

Joshua Greenstein

New School for Social Research 


\author{
Copyright $\odot 2010$ \\ International Policy Centre for Inclusive Growth \\ United Nations Development Programme
}

International Policy Centre for Inclusive Growth (IPC - IG)

Poverty Practice, Bureau for Development Policy, UNDP

Esplanada dos Ministérios, Bloco $0,7^{\circ}$ andar

70052-900 Brasilia, DF - Brazil

Telephone: +556121055000

E-mail: ipc@ipc-undp.org • URL: www.ipc-undp.org

The International Policy Centre for Inclusive Growth is jointly supported by the Poverty Practice, Bureau for Development Policy, UNDP and the Government of Brazil.

\title{
Rights and Permissions
}

All rights reserved.

The text and data in this publication may be reproduced as long as the source is cited. Reproductions for commercial purposes are forbidden.

The International Policy Centre for Inclusive Growth disseminates the findings of its work in progress to encourage the exchange of ideas about development issues. The papers are signed by the authors and should be cited accordingly. The findings, interpretations, and conclusions that they express are those of the authors and not necessarily those of the United Nations Development Programme or the Government of Brazil.

Working Papers are available online at www.ipc-undp.org and subscriptions can be requested by email to ipc@ipc-undp.org 


\title{
HOW SHOULD MDG IMPLEMENTATION BE MEASURED: FASTER PROGRESS OR MEETING TARGETS?*
}

\author{
Sakiko Fukuda-Parr ${ }^{* *}$ and Joshua Greenstein ${ }^{* * *}$
}

\begin{abstract}
This paper questions the methodology that is widely used to assess progress in implementing the Millennium Development Goals (MDGs), a methodology that asks whether the targets are likely to be met. This approach is inappropriate, since the MDGs were neither designed as nor intended to be planning targets. They were political commitments, made by world leaders, that define priorities in a normative framework and that can be used as benchmarks in evaluating progress. In this framework the appropriate question is whether more is being done to live up to that commitment, resulting in faster progress. We present a methodology and analysis using this new framework, and find that our assessment of "progress" differs considerably from that arising from the conventional methodology. For example, while access to safe water is touted as an MDG success, only a third of the countries improved at a faster rate. Overall, in most indicators and in most countries, progress has not accelerated.
\end{abstract}

\section{INTRODUCTION}

The Millennium Development Goals (MDGs) are derived from the Millennium Declaration, adopted by the 2000 UN General Assembly when world leaders made commitments to end world poverty, as well as to secure peace, human rights and democracy in the new millennium. Like all UN goals, the MDGs are best viewed as a set of norms, not as specific planning targets. ${ }^{1}$ They are ends rather than means, and do not come with a specific set of new development strategies for meeting the goals. They are "not a technocratically defined set of goals that come with an analysis of development constraints accompanied with a finely tuned set of policy prescriptions" (Fukuda-Parr, 2004: 397). For this reason, it does not make sense to treat the goals as hard planning targets. One of the critically important aspects of the MDGs, however, is that they do provide concrete goals against which poverty reduction can be measured. They offer a framework for accountability. Governments can be held accountable by their people and by civil society. The international community can hold

\footnotetext{
* The authors are very grateful to David Stewart, who contributed to earlier conceptualisation of this paper.

** Graduate Program in International Affairs, New School.

*** New School for Social Research.
} 
national governments accountable, and can be held accountable by them. If this newfound accountability is to be worthwhile, though, the method of determining progress, or lack thereof, must be the correct one.

This paper argues that rather than treating the goals as hard targets, the more important question is whether the introduction of the MDGs has accelerated poverty reduction.

The prevailing method of monitoring progress-by measuring whether progress is on track to achieving the targets-is not consistent with the purpose of the MDGs. The paper proposes an alternative method of measuring acceleration in the rate of progress. First, we review the current methodologies used to measure progress on the MDGs and how these assessments have been used in criticisms of the MDGs as planning targets. Then we present our alternative framework and the results of our analysis, using a new methodology to assess progress. The final section concludes.

\section{CURRENT FRAMEWORK FOR MEASURING PROGRESS: MDGS AS PLANNING TARGETS}

In 2005, then Secretary-General Kofi Annan's report on the progress of the Millennium Declaration described the MDGs as "globally accepted benchmarks of broader progress" (United Nations, 2005: 10). Current UN documents, however, tend to describe the goals as "time-bound and quantified targets" (United Nations, 2006) with "a deadline of 2015" (United nations, n.d.). The difference is not insignificant. Since the Millennium Declaration was adopted in 2000, governments and UN agencies have monitored progress towards achievement of the MDGs at global, regional and national levels. For each of the eight goals there are specific targets or subgoals, and for each target there is at least one indicator. These indicators are used to determine progress on each target and goal (see Table 1 for list of all goals, targets and indicators). The methodology used in this monitoring has been to assess current trends in the indicators relative to the defined target. The question asked is "will the MDG targets be achieved by 2015?" Either 1990 data is compared to the most recent data directly in order to determine if there has been improvement, or extrapolations of 1990 to present trends are used to determine if the world or a specific region is "on track" to meet the mark by 2015. This approach to assessing programmes assumes that the MDGs were indeed intended to be planning targets. Nearly all evaluations that attempt to determine the success or failure of the MDGs are based on this approach.

Some of the UN officials involved in devising the goals, however, never intended them to be used in this manner. Jan Vandemoortele, one of the co-chairs of the UN group that put the MDGs together in 2001, has written that the goals are meant to be taken as global targets based on previous global, not national, trends. He argues that the targets were not designed to be met by particular countries or regions, and were instead "meant to encourage countries to strive for accelerated progress" (Vandemoortele, 2007: 1).Hamid Tabatabai of the International Programme on the Elimination of Child Labour, agrees: "The MDGs were presumably meant to accelerate trends through reforms in developing countries ... and increased flows of aid and investment" (Tabatabai, 2007: 1). But Tabatabai also notes that the UN system's own documents constantly contradict Vandemoortele's interpretation (Tabatabai, 2007: 1).

As Tabatabai correctly points out, and as we document below, UN reports assessing the MDGs are full of statements discussing whether countries or regions are on track to meet the goals- 
precisely the kind of statements that Vandemoortele describes as erroneous. Conversely, as far as the present authors are aware, there has been scant if any assessment of whether the goals have accelerated progress in line with the indicators since implementation.

TABLE 1

Millennium Development Goals, Targets and Indicators

\begin{tabular}{|c|c|}
\hline Goal & Targets and Indicators \\
\hline $\begin{array}{l}\text { Goal 1: eradicate } \\
\text { extreme poverty } \\
\text { and hunger }\end{array}$ & 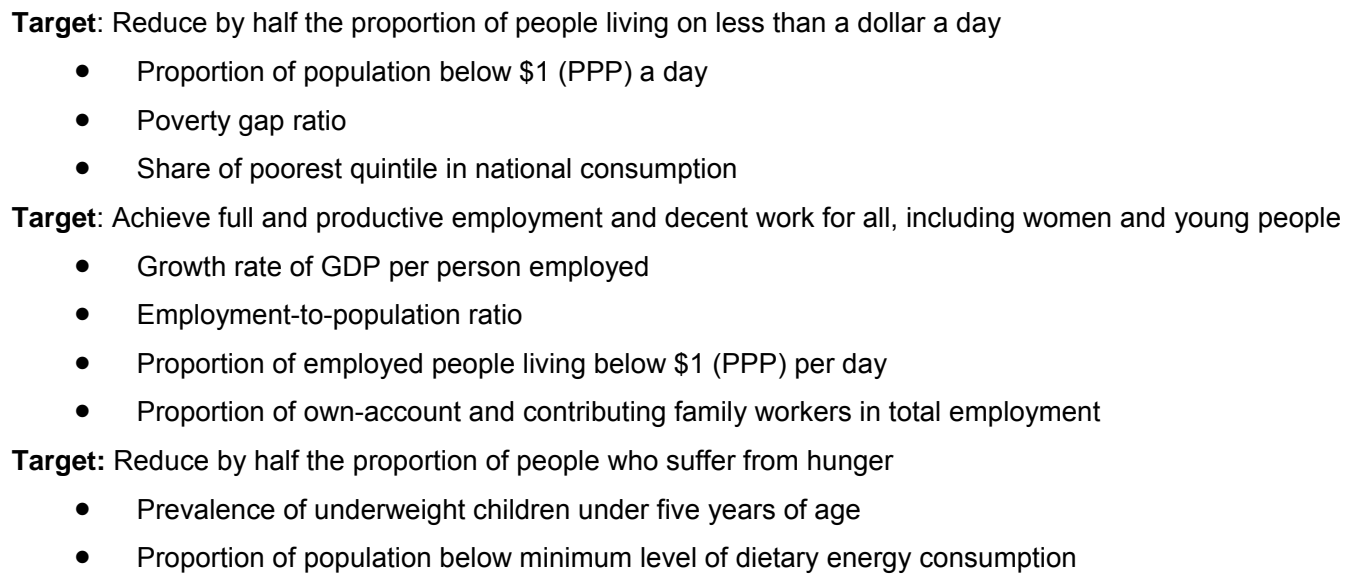 \\
\hline $\begin{array}{l}\text { Goal 2: achieve } \\
\text { universal primary } \\
\text { education }\end{array}$ & $\begin{array}{l}\text { Target : Ensure that all boys and girls complete a full course of primary schooling } \\
\text { - Net enrolment ratio in primary education } \\
\text { - } \quad \text { Proportion of pupils starting grade } 1 \text { who reach last grade of primary } \\
\text { - Literacy rate of } 15-24 \text { year-olds, women and men }\end{array}$ \\
\hline $\begin{array}{l}\text { Goal 3: promote } \\
\text { gender equality } \\
\text { and empower } \\
\text { women }\end{array}$ & $\begin{array}{l}\text { Target: Eliminate gender disparity in primary and secondary education preferably by } 2005 \text {, } \\
\text { and at all levels by } 2015 \\
\text { - Ratios of girls to boys in primary, secondary and tertiary education } \\
\text { - Share of women in wage employment in the non-agricultural sector } \\
\text { - Proportion of seats held by women in national parliament }\end{array}$ \\
\hline $\begin{array}{l}\text { Goal 4: reduce } \\
\text { child mortality }\end{array}$ & $\begin{array}{l}\text { Target: Reduce by two thirds the mortality rate among children under five } \\
\text { - Under-five mortality rate } \\
\text { - Infant mortality rate } \\
\text { - Proportion of } 1 \text { year-old children immunised against measles }\end{array}$ \\
\hline $\begin{array}{l}\text { Goal 5: improve } \\
\text { maternal health }\end{array}$ & $\begin{array}{l}\text { Target: Reduce by three quarters the maternal mortality ratio } \\
\text { - Maternal mortality ratio } \\
\text { - Proportion of births attended by skilled health personnel } \\
\text { Target: Achieve, by } 2015 \text {, universal access to reproductive health } \\
\text { - Contraceptive prevalence rate } \\
\text { - Adolescent birth rate } \\
\text { - Antenatal care coverage (at least one visit and at least four visits) } \\
\text { - Unmet need for family planning }\end{array}$ \\
\hline $\begin{array}{l}\text { Goal 6: combat } \\
\text { HIVIAIDS, malaria } \\
\text { and other } \\
\text { diseases }\end{array}$ & $\begin{array}{l}\text { Target: Halt and begin to reverse the spread of HIVIAIDS } \\
\text { - HIV prevalence among population aged } 15-24 \text { years } \\
\text { - Condom use at last high-risk sex } \\
\text { - Proportion of population aged } 15-24 \text { years with comprehensive correct knowledge of HIV/AIDS } \\
\text { - Ratio of school attendance of orphans to school attendance of non-orphans aged 10-14 years }\end{array}$ \\
\hline
\end{tabular}




\begin{tabular}{|c|c|}
\hline $\begin{array}{l}\text { Goal 6: combat } \\
\text { HIVIAIDS, malaria } \\
\text { and other } \\
\text { diseases }\end{array}$ & $\begin{array}{l}\text { Target: Achieve, by } 2010, \text { universal access to treatment for HIVIAIDS for all those who need it } \\
\text { - Proportion of population with advanced HIV infection with access to antiretroviral drugs } \\
\text { Target: Halt and begin to reverse the incidence of malaria and other major diseases } \\
\text { - Incidence and death rates associated with malaria } \\
\text { - Proportion of children under } 5 \text { sleeping under insecticide-treated bednets } \\
\text { - } \quad \text { Proportion of children under } 5 \text { with fever who are treated with appropriate anti-malarial drugs } \\
\text { - Incidence, prevalence and death rates associated with tuberculosis } \\
\text { - Proportion of tuberculosis cases detected and cured under directly observed treatment short course }\end{array}$ \\
\hline $\begin{array}{l}\text { Goal 7: ensure } \\
\text { environmental } \\
\text { sustainability }\end{array}$ & $\begin{array}{l}\text { Target: Integrate the principles of sustainable development into country policies and programmes; reverse loss } \\
\text { of environmental resources } \\
\text { Target: Reduce biodiversity loss, achieving, by } 2010 \text {, a significant reduction in the rate of loss } \\
\text { - Proportion of land area covered by forest } \\
\text { - CO2 emissions, total, per capita and per } \$ 1 \text { GDP (PPP) } \\
\text { - Consumption of ozone-depleting substances } \\
\text { - Proportion of fish stocks within safe biological limits } \\
\text { - Proportion of total water resources used } \\
\text { - Proportion of terrestrial and marine areas protected } \\
\text { Target: Reduce by half the proportion of people without sustainable access to safe drinking water } \\
\text { and basic sanitation } \\
\text { - Proportion of population using an improved drinking water source } \\
\text { Target: Achieve significant improvement in lives of at least } 100 \text { million slum dwellers, by } 2020 \\
\text { - Proportion of urban population living in slums }\end{array}$ \\
\hline $\begin{array}{l}\text { Goal 8: develop a } \\
\text { Global } \\
\text { Partnership for } \\
\text { Development }\end{array}$ & $\begin{array}{l}\text { Target : Develop further an open, rule-based, predictable, non-discriminatory trading and financial system } \\
\text { Target: Address the special needs of the least developed countries } \\
\text { Target : Address the special needs of landlocked developing countries and small island developing States } \\
\text { (through the Programme of Action for the Sustainable Development of Small Island Developing States and the } \\
\text { outcome of the twenty-second special session of the General Assembly) } \\
\text { Target: Deal comprehensively with the debt problems of developing countries through national and international } \\
\text { measures in order to make debt sustainable in the long term } \\
\text { Official development assistance (ODA) } \\
\text { - Net ODA, total and to the least developed countries, as percentage of OECD/DAC donors' gross } \\
\text { - } \quad \text { Proportional income of total bilateral, sector-allocable ODA of OECD/DAC donors to basic social services (basic } \\
\text { - } \quad \text { Proportion of bilateral official development assistance of OECD/DAC donors that is untied } \\
\text { - ODA received in landlocked developing countries as a proportion of their gross national incomes } \\
\text { - ODA received in small island developing States as a proportion of their gross national incomes } \\
\text { Market access } \\
\text { - Proportion of total developed country imports (by value and excluding arms) from developing countries } \\
\text { - And least developed countries, admitted free of duty } \\
\text { - Average tariffs imposed by developed countries on agricultural products and textiles and clothing from } \\
\text { developing countries } \\
\text { Paricultural support estimate for OECD countries as a percentage of their gross domestic product } \\
\text { Pron oDA provided to help build trade capacity }\end{array}$ \\
\hline & \\
\hline
\end{tabular}




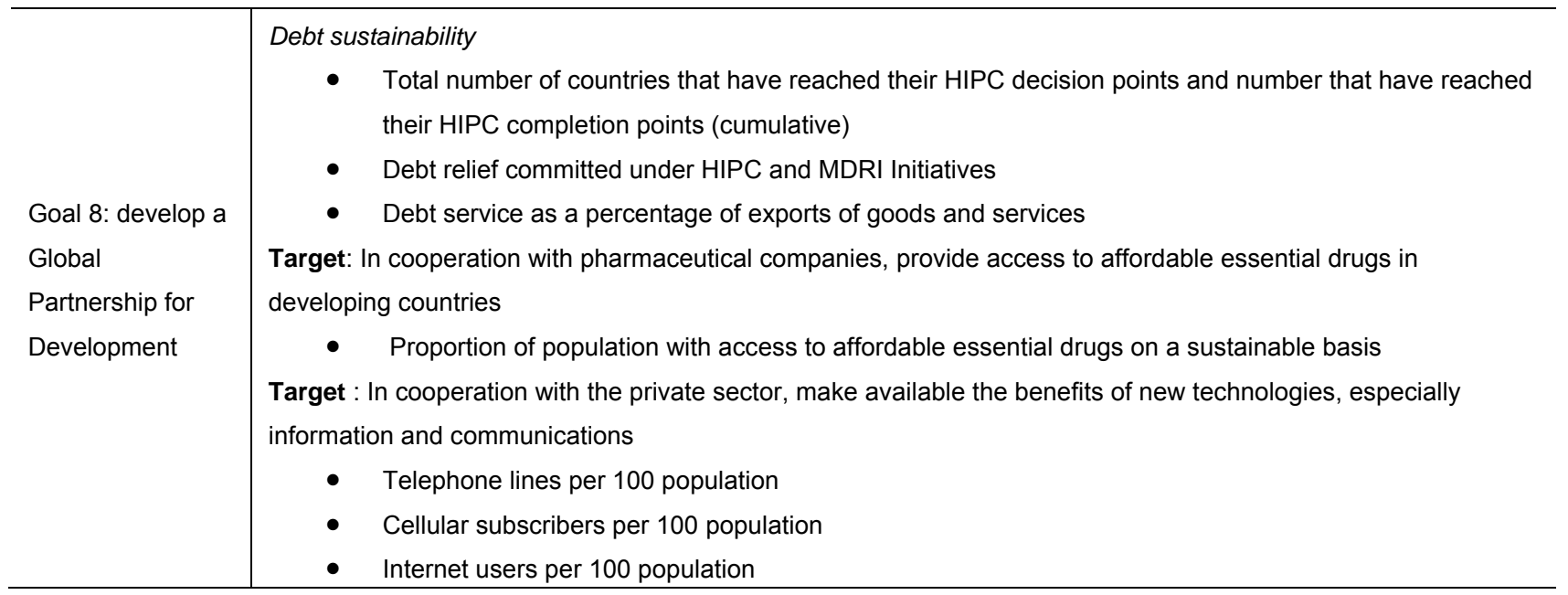

Source: United Nations Development Programme, 'About the MDGs: Basics':

http://www.undp.org/mdg/basics.shtml.

The UN's 2009 Millennium Development Goals (UN MDG Report) focuses almost exclusively on the question of meeting the targets by 2015, and whether progress towards those targets has been achieved since the implementation of the MDGs. For most indicators, improvement is judged using the 1990 data as a baseline. In some instances, data from 2000 is also included to "show progress since the Declaration was signed" (United Nations, 2009: 54). There is virtually no attempt to compare pre-1990 trends with post-1990 trends in the indicators, or 1990-2000 trends with post-2000 trends. This pattern holds true even for indicators that include a 2000 data point. For example, the report notes that total deforestation was less from 2000 to 2005 than from 1990 to 2000 , but it includes only average annual total net loss for each period, with no indication of the year-to-year trend during these periods, or of whether a shift in the annual change began in the second period (United Nations, 2009: 43). This approach holds for indicators that are perceived as successful as well as those perceived as failing. For example, it is reported that the goal related to the percentage of the population with access to drinking water is on track to be met.

A comparison of regional 1990 and 2006 statistics illustrates significant improvement in this indicator (United Nations, 2009: 46). This improvement is undoubtedly good news, but there is no comparison with pre-1990 trends, nor any indication of how the rate of change has evolved over the 1990-2006 period. Similarly, the report states that the world is not on course to meet the universal primary education goal by 2015 , though the rate of school enrolment has been improving. This improvement is revealed by a comparison of worldwide and regional 1999 and 2006 data (United Nations, 2009: 14). There is no discussion of how this improvement compares to historical trends, nor whether the rate of improvement has been changing in the most recent period. The report indicates that the goal is unlikely to be met, but not whether the MDG declaration has had a positive effect on enrolment.

Other major international institutions use a similar metric to measure progress. The World Bank's 2009 Global Monitoring Report also discusses the MDGs as hard targets. Much of the report's focus is on whether the goals at the country, regional or global levels are "on track" to be achieved by 2015 . For each goal, a graph illustrates the percentage of countries that have "achieved" the goal, that are "on track," "off track" and "seriously off track" (World Bank, 2009: 17). 
Another graph compares the current global levels of the first seven indicators with the required levels for these indicators to be on track for 2015 (World Bank, 2009: 16). Discussion of relative success or difficulties in meeting each goal centres on absolute achievement rather than any change in trend. For example, the goal for poverty reduction is considered "in reach", largely because of "strong economic growth in developing countries in the past decade" (World Bank, 2009: 13). The Bank also reports that the goals for gender parity in primary and secondary education, as well as the goal for access to safe water, are on track to be met at the global level (World Bank, 2009: 15). Progress on child mortality in developing countries is deemed "insufficient" to meet the 2015 target after an examination of the 1990 and 2006 statistics (World Bank, 2009: 19). There is no inquiry into whether there has been a postMillennium Declaration change in global trends related to any of these indicators. In an annex entitled "Monitoring the MDGs", the Bank does provide graphs with trend lines from 1990 to 2006 for selected indicators, alongside its 1990 and 2006 absolute-level comparisons. Even here, however, the graph is only used to compare the actual trend with the trend line that would be required to meet the goal (World Bank, 2009: 203-219). The focus remains on whether the goal will be met by 2015 , and the question of changes in trend relative to the MDGs remains unasked. The fixation on the goals as targets is clearly illustrated when, after providing some genuinely disheartening statistics on hunger, school enrolment and other issues, the report makes the seemingly tautological observation that these are "numbers that would be far lower if the world were on track on the MDGs" (World Bank, 2009: 4).

Regional banks such as the Asian Development Bank (ADB) and the African Development Bank (AFDB) use similar methodologies. The ADB's 2007 report, The Millennium Development Goals. Progress in Asia and the Pacific, is devoted to "identifying which countries are on or off track for specific MDG targets" (Asian Development Bank, 2007: 3). It divides countries into four categories: "early achiever" (already achieved the 2015 target); "on track" (expected to meet the target); "off track-slow" (expected to meet the target, but not by the 2015 deadline); and "off track-no progress, regressing." Countries are placed in these categories on the basis of the trend since 1990. If the goals are to be met, what is necessary "for many countries is to break away from the predicted path" (Asian Development Bank, 2007: 3). Whether the "early achievers" or "ontrack" countries have broken away from previous paths during the 1990-2007 period is again left unexamined. The AFDB's Assessing Progress in Africa toward the Millennium Development Goals similarly examines the relative success of the goals almost exclusively by comparing absolute levels circa 1990 with absolute present levels for individual countries. In some cases, 1990$2005 / 6$ trends are the method of choice, but no attempt is made to compare pre- and postMillennium Declaration trends (African Development Bank, 2009).

Some non-governmental organisations (NGOs) and watchdog organisations do take approaches that differ slightly from those of the official governmental bodies. For example, Social Watch, an international network of citizen's organisations working on issues of poverty and social justice, describes the MDGs as "minimum benchmarks" of human rights entitlements and argues that the MDGs should be "less about meeting targets but more about honouring human rights obligations" (Social Watch, 2005). There may be little to disagree with in that sentiment, but if the MDGs are to be about fulfilling obligations rather than meeting specific goals, there is still a need to examine the extent to which those obligations are being met. 


\subsection{IMPLICATIONS OF THE PREVAILING FRAMEWORK}

Measuring progress on the MDGs as a planning targets framework has given rise to sharp critiques. The most prominent criticisms of the MDGs usually centre on the arbitrary way in which the individual goals are defined, the unfairness or unfeasibility of the goals, and the unlikelihood that the goals will be reached. Ashwani Saith has pointed out numerous flaws in the list of goals, targets and indicators for their concepts, and data availability that undermine their potential use as programming tools (Saith, 2006). William Easterly has described the goals as "poorly and arbitrarily designed to measure progress" (Easterly, 2009a: 26). He explains that these targets could have been defined in several different ways: by absolute or percentage changes, by change targets versus level targets, and by positive or negative indicators (Easterly, 2009a: 27). All of these choices have ramifications for the likelihood of the goals being met. The choices were inconsistent, and the logic behind how each goal was defined is not always clear.

Easterly further argues that some of these arbitrary choices have resulted in bias against Africa, in that African countries are less likely to meet the goals and so will be dubbed failures. For example, Goal 2, the achievement of universal primary education, is an absolute-level goal. The goal could have been defined as a certain percentage-change in enrolment levels. It is significantly more difficult to achieve in countries or regions where initial enrolment is lower. Even if there are significant improvements in enrolment, therefore, these countries or regions may be labelled as failing (Easterly, 2009a: 29). Other critics point to the confusion stemming from whether goals should be considered on a global, regional or country level. Michael Clemens notes that some of the goals, by their nature, apply to every individual country, even if they are meant to be achieved globally. For example, the goal of attaining worldwide universal primary education is obviously only possible if every single country attains it. Conversely, the goal of halving the percentage of people living in poverty worldwide may be reached, but almost entirely because of growth in India and China-which, Clemens points out, has little or nothing to do with aid interventions and tells us nothing about the progress in any other countries (Clemens, 2007: 738).

For both Clemens and Easterly however, the larger criticism is that the goals will not or cannot be met. Going beyond Easterly's criticism that the goals were unfair and difficult to meet for Africa, Clemens has written that the goals in general were inherently impossible to meet because of their poor design (Easterly, 2009a: 736). He notes a 2004 World Bank estimate that in order to halve poverty, the average African country would require GDP growth of 7 per cent for 15 years. In the 15 years before MDG implementation, 1985-2000, only five countries in the world averaged GDP growth that high. This is far from the only goal that Clemens finds unrealistic. For the 38 countries with primary school enrolment rates below 80 per cent, achieving a 95 per cent enrolment rate (still below the goal of 100 per cent) would require progress that is, according to Clemens, completely without historically precedent. Every one of these 38 countries would have to improve enrolment at a rate that has not been achieved by a single country for which post-1960 data is available (Easterly, 2009a: 742). These arguments were powerful even before the current economic crisis, which has heightened the pessimism of both MDG proponents and critics alike. After the release of the 2009 UN MDG Report, Easterly delivered his final verdict on his blog Aidwatch: "Let's face it: it's over. The MDGs will not be met ... the point of the MDG campaign was that it precisely defined success and failure using specific goals. So on its own terms, it is a failure" (Easterly, 2009b). 
While these criticisms are convincing, the question of whether the MDGs have had a positive impact on individual countries or on the world as a whole is not addressed. Both Clemens and Easterly acknowledge the positive impact of the goals as motivators or aspirations. Clemens writes: "there can be little doubt that the MDGs helped galvanise the aid community and reverse the aid declines" (Clemens, 2007: 747). On his blog, Easterly states: "the inspirational enthusiasm and increased efforts surrounding the MDGs probably did contribute to progress on specific efforts and some partial success stories" (Easterly, 2009b). More concretely, development aid had been on the rise before the crisis, culminating in 2008 in what the UN reports as the highest official development aid dollar figure ever recorded (United Nations, 2009: 48). Virtually all of the discussion surrounding the goals, however, treats them as hard targets and determines success or failure on the basis of whether those targets will be reached. Nobody seems to be asking whether the MDGs and the subsequent greater focus on aid and its amounts have actually led to an improvement on historical trends in these areas, and to faster progress towards ending human poverty. Another interpretation of MDG success or failure is needed.

\section{ALTERNATIVE FRAMEWORK: MDGs AS NORMATIVE GOALS AND EVALUATIVE BENCHMARKS}

Clearly, treating the MDGs as targets entails serious conceptual problems. This paper presents an alternative framework for evaluating progress. It argues that the MDGs should be used as benchmarks of progress and that progress should be evaluated by asking whether, since implementation, the pace of poverty reduction has accelerated along the MDG dimensions, targets and indicators. The MDGs have unquestionably mobilised the UN system and the international donor community. They have also had an impact on policy priorities. Rather than fixating on attaining a specific level, it may be more revealing to examine if this increased mobilisation and change in priorities has had any effect on the pace of poverty eradication. Further, it makes more sense to focus on the progress of individual countries rather than the world as a whole, or even regions, so as to avoid effects such as China's growth obscuring decline or stagnation elsewhere.

\subsection{METHODOLOGY: ACCELERATING PROGRESS}

This paper presents the results of an empirical analysis of country-level trends since 1990, comparing the rate of change in the periods before and after adoption of the MDGs.

The analysis covers all countries of the world for which sufficient data are available. For each country and each indicator, data for three years were found: the earliest available year, going back to 1990; a middle year from 2000 to 2003; and the most recent year available. The UN "roadmap" outlining strategies for achieving the MDGs was unveiled in September 2001. Since new policies take time to implement and have an effect, we have tried to allow for one year of lag time and have used 2003 as the middle year whenever possible. Countries were excluded if there were insufficient data to satisfactorily form three periods using these guidelines. Several indicators were excluded entirely because of a lack of necessary data for a large number of countries. ${ }^{2}$ The source of all data was the official United Nations site for the MDG Indicators. ${ }^{3}$ Once data for the three years were found for each indicator and country, an annualised rate of change was calculated for the period from the first year to the second, and from the second to the third. A comparison was then made between the rates of change for 
the two periods in order to determine if there had been an acceleration of improvement. ${ }^{4}$ In addition to these rates of change, the percentage of countries with absolute improvement from 1990, or the earliest possible year after 1990, to most recent data was calculated for each indicator.

The calculations were made using the following formula:

$$
=\operatorname{IF}\left(\left(D_{M I D}-D_{F S T}\right) /\left(Y_{M I D}-Y_{F S T}\right)>=\left(D_{L S T}-D_{M I D}\right) /\left(Y_{L S T}-Y_{M I D}\right) \text {, "No Acceleration", "Acceleration” }\right)
$$

where $\mathrm{Y}_{\mathrm{FST}}=$ earliest possible year to $1990, \mathrm{Y}_{\mathrm{MID}}=2000-2003$, and $\mathrm{Y}_{\mathrm{LST}}=$ most recent available year. $D_{\mathrm{FST}}=$ first year indicator value, $D_{\mathrm{MID}}=$ second year indicator value, and $D_{\mathrm{LST}}=$ third year indicator value.

This formula was used to calculate and compare the average rates of change for each period, for each country and indicator, as described above.

While this method of comparing absolute changes as linear phenomena is admittedly quite simple, the official UN and World Bank/regional bank documents attempting to project whether countries or regions are on track for the goals often use methods that are similarly very simple. As in our analysis, the projections for increasing indicators (indicators in which a higher level is better) are based on a linear model of the average rate of change between two data points, from the earliest possible year going back to 1990 and the most recent year available.

The formal formula used by the United Nations Development Programme (UNDP) and the ADB for estimating trends for "increasing indicators" in their report on the MDGs progress in Asia, using the same symbols as above for easier comprehension, is given as:

$$
D_{L S T}=D_{F S T}+q^{\left(Y_{L S T}-Y_{F S T}\right)}
$$

where $\left.\mathrm{q}=\left(D_{\mathrm{LST}}-D_{\mathrm{FST}}\right) / \mathrm{Y}_{\mathrm{LST}}-\mathrm{Y}_{\mathrm{FST}}\right)$.

Predictions about when the goals will be met are then made by keeping this rate of change constant and extrapolating into the future. The essential difference between these calculations and our own is that these formulas only calculate one rate, from the earliest possible year since 1990 to the most recent year-whereas we have added a middle year and calculated the rate of change for two periods for the purposes of comparison.

For "decreasing indicators" (indicators in which a lower level is better) the ADB and UNDP use a slightly more complex formula:

$$
D_{L S T}=D_{F S T}(1+r)\left(Y_{L S T}-Y_{F S T}\right)
$$

where " $r$ " represents the average growth rate between $Y_{F S T}$ and $Y_{L S T}$, calculated as a slope that declines at a decreasing rate. ${ }^{5}$ This method takes into account that indicators will often improve at decreasing rates. This is a step that we have not taken in our calculations at this point. For this round of calculations, we have also treated decreasing indicators as linear. We address this issue more fully in our section on child mortality.

The other common method of evaluating progress in the UN's 2009 report consists mainly of direct comparisons between the absolute-level aggregate regional or world data for several different years - for example, a direct comparison between 1990 and 2007 levels to determine 
if there has been improvement. The method is described simply as using aggregate regional figures, with the 1990 figures as a baseline, to "track advances over time" (United Nations, 2009: 54). This use of absolute-level comparisons as a basis for measuring progress is also consistent with our methodology.

\subsection{FINDINGS}

Table 2 presents a summary of our provisional findings. This table represents 25 indicators and all countries for which data were available. The first two columns list the indicator and goal. The second column gives the total number of countries for which data were available, and the third column gives the percentage of countries that had an accelerated rate of improvement in the second period. For example, for the first indicator listed, employment-to-population ratio, sufficient data were available for 177 countries; of those, 64 per cent experienced accelerated improvement in the second period. Also included, in column 4, is the percentage of countries that showed an absolute improvement in the most recent year relative to the earliest available year. For the first indicator, 56 per cent of countries for which data were available. For the indicator "people living with HIV 15-49 years old, \%", data were only available for the years 2001-2007. Only a comparison between these two years is included in the table.

TABLE 2

Have Countries Accelerated Improvement towards the Goals?

\begin{tabular}{|c|c|c|c|c|}
\hline Goal & Indicator & $\begin{array}{c}\text { Total } \\
\text { countries } \\
\text { for which } \\
\text { data } \\
\text { available } \\
\end{array}$ & $\begin{array}{l}\% \text { showing } \\
\text { improved } \\
\text { rate in post- } \\
\text { MDG period }\end{array}$ & $\begin{array}{c}\text { \% showing } \\
\text { overall } \\
\text { improvement } \\
\text { first to last year }\end{array}$ \\
\hline 1 & Employment to Population ratio, both sexes, percentage & 177 & $64 \%$ & $56 \%$ \\
\hline 1 & Population Below \$1 per day, (PPP), Percentage & 51 & $51 \%$ & $55 \%$ \\
\hline 1 & Growth Rate of GDP per Person Employed, Percentage & 163 & $42 \%$ & $62 \%$ \\
\hline 2 & Total Net Enrolment Ratio in Primary Education, Both Sexes & 135 & $35 \%$ & $68 \%$ \\
\hline 3 & Seats held by women in national parliament, percentage & 180 & $50 \%$ & $82 \%$ \\
\hline 3 & Gender Parity Index in Primary Level Enrolment & 179 & $46 \%$ & $48 \%$ \\
\hline 3 & Gender Parity Index in Secondary Level Enrolment & 166 & $47 \%$ & $48 \%$ \\
\hline 3 & Gender Parity Index in Tertiary Level Enrolment & 115 & $47 \%$ & $80 \%$ \\
\hline 3 & Share of women in wage employment in non-agricultural sector & 106 & $37 \%$ & $73 \%$ \\
\hline 4 & Children 1 year old immunised against measles, percentage & 191 & $46 \%$ & $73 \%$ \\
\hline 4 & Children under 5 mortality rate per 1000 live births & 194 & $32 \%$ & $96 \%$ \\
\hline 4 & Infant Mortality Rate 0-1 year per 1000 live births & 194 & $29 \%$ & $95 \%$ \\
\hline 5 & Births attended by skilled health personnel, percentage & 87 & $49 \%$ & $72 \%$ \\
\hline 5 & $\begin{array}{l}\text { Current contraceptive use among married women, ages } 15-49 \text {, any } \\
\text { method, percentage }\end{array}$ & 59 & $24 \%$ & $85 \%$ \\
\hline 6 & People Living with HIV 15-49 years old, percentage & 142 & & $20 \%$ \\
\hline 6 & Tuberculosis detection rate under DOTS & 174 & $49 \%$ & $67 \%$ \\
\hline 6 & Tuberculosis death rate per year per 100,000 population & 210 & $44 \%$ & $69 \%$ \\
\hline 6 & Tuberculosis prevalence rate per 100,000 population & 210 & $33 \%$ & $78 \%$ \\
\hline 6 & Tuberculosis incidence rate per year per 100,000 population & 210 & $28 \%$ & $60 \%$ \\
\hline 7 & Slum population as percentage of urban, percentage & 91 & $76 \%$ & $79 \%$ \\
\hline 7 & Carbon Dioxide Emissions, metric tons $\mathrm{CO} 2$ per capita, (CDIAC) & 208 & $46 \%$ & $37 \%$ \\
\hline
\end{tabular}




\begin{tabular}{lllll}
\hline 7 & Proportion of the population using improved drinking water sources, total & 126 & $34 \%$ & $78 \%$ \\
7 & Proportion of the population using improved sanitation facilities, total & 153 & $34 \%$ & $61 \%$ \\
7 & Terrestrial and marine areas protected to total territorial area, percentage & 216 & $6 \%$ & $72 \%$ \\
\hline 8 & $\begin{array}{l}\text { Debt service as percentage of exports of goods and services and net } \\
\text { income }\end{array}$ & 111 & $65 \%$ & $76 \%$ \\
\hline
\end{tabular}

Only five of the 24 indicators for which two periods were measured showed post-MDG accelerated improvement in more than 50 per cent of countries: debt service; slum population as percentage of urban population; seats held by women in national parliament; population living on less than one dollar a day; and employment-to-population ratio. Even among these five, "population living on less than one dollar" and "seats held by women in national parliament" are at almost exactly 50 per cent. For the twenty-fifth indicator, HIV prevalence, the available data pertain only to the post-MDG period, so a two-period comparison is not possible. Nonetheless, in this wholly post-MDG implementation period (2001-2007), HIV prevalence has risen in 80 per cent of the countries for which data are available. Our conclusion is that there has not been a post-MDG acceleration of improvement in most countries for the significant majority of indicators.

A comparison of these observations with those listed in column 4 illustrates the significance of this new method. For example, as mentioned earlier, access to safe water has been touted as an MDG success. The UN reported that the world was on course to meet this target "ahead of schedule", a conclusion that was reached using a regional comparison of 1990 and 2006 percentages (United Nations, 2009: 45). Our finding that 78 per cent of the 126 countries under study experienced an improvement in this period matches that conclusion. But a comparison of improvement rates pre- and post-MDG implementation tells a different story. In only about a third of the countries studied did improvement accelerate in the second period. Again, it is surely positive that the world seems to be on its way to providing access to clean water to all of its inhabitants, but the extent to which this positive news is related to the MDGs is anything but clear. Similar patterns are observable for several other indicators. For example, for the "births attended by skilled health personnel" indicator, there has been an improvement in 72 per cent of the countries studied since 1990. In less than half, however, has there been any acceleration since MDG implementation. In fact, of the 24 indicators for which this type of comparison can be made, there are only two in which this method of calculation does not produce a "worse" result. This disparity clearly illustrates why the use of 1990 as a baseline is problematic. More disturbingly, in a significant number of countries there has been a regression for these indicators compared to absolute 1990 levels. At least a third of countries have not improved or have regressed in 12 indicators. Even for indicators in which many countries have been improving since 1990, if they have not been improving at accelerated rates since implementation it must be asked to what extent the MDGs have affected this overall improvement.

\subsection{LEAST DEVELOPED COUNTRIES}

The same methodology and analysis as above was repeated for the least developed countries (LDCs) and sub-Saharan African countries. The classifications used for both groups were also taken from the UN MDG indicators monitor. The reason for the focus on these two groups is that they are so vitally important to the MDGs, and to a genuine acceleration in the worldwide 
eradication of poverty. It can also be assumed that the countries in these two groups are disproportionate recipients of international aid, and of the attention and energy of UN development programmes. By definition, moreover, for many of these indicators the LDCs will be at a lower initial level than most other countries, and thus they have much more need for (as well as a greater prospect of) accelerated improvement. For both the LDCs and sub-Saharan Africa, our methodology did reveal more positive results. In both cases, most countries showed accelerated improvement in more indicators (though still far from all).

Table 3 gives the results for the LDCs, which by our measure fared better than the world as a whole. In 13 of the 24 indicators, 50 per cent or more of countries experienced accelerated improvement in the second period. For 19 of the 25 indicators, half or more of the LDCs showed overall improvement. Despite the better relative achievement, our method still produces very different answers than the standard measure of post-1990 improvement or absolute achievement of goals. There are several individual indicators that exemplify this difference. For "proportion of the population using improved access to drinking water", 83 per cent of the LDCs have improved since the beginning of the period measured, but less than half have shown an increased rate of improvement in the second period. A similar pattern prevails for the "primary school enrolment" indicator: 86 per cent of countries have improved post1990 , but less than half have seen any acceleration in improvement post-MDG. Overall, of the 24 indicators studied, in only three does our method of rate comparison not show a lower percentage of LDCs improving than a simple absolute improvement since 1990 measure.

TABLE 3

\section{Least Developed Countries}

\begin{tabular}{|c|c|c|c|c|}
\hline Goal & Indicator & $\begin{array}{c}\text { Total LDCs } \\
\text { for which } \\
\text { data } \\
\text { available }\end{array}$ & $\begin{array}{l}\text { \% showing } \\
\text { improved } \\
\text { rate in post- } \\
\text { MDG period }\end{array}$ & $\begin{array}{c}\text { \% showing } \\
\text { overall } \\
\text { improvement } \\
\text { first year to last } \\
\text { year }\end{array}$ \\
\hline 1 & Population below $\$ 1$ per day, (PPP), percentage & 6 & $67 \%$ & $100 \%$ \\
\hline 1 & Growth Rate of GDP per Person Employed, Percentage & 40 & $45 \%$ & $65 \%$ \\
\hline 2 & Total Net Enrolment Ratio in Primary Education, Both Sexes & 29 & $45 \%$ & $86 \%$ \\
\hline 3 & Seats held by women in national parliament, percentage & 44 & $59 \%$ & $80 \%$ \\
\hline 3 & Gender Parity Index in Primary Level Enrolment & 42 & $57 \%$ & $76 \%$ \\
\hline 3 & Gender Parity Index in Secondary Level Enrolment & 36 & $50 \%$ & $83 \%$ \\
\hline 3 & Gender Parity Index in Tertiary Level Enrolment & 18 & $67 \%$ & $78 \%$ \\
\hline 3 & Share of women in wage employment in non-agricultural sector & 3 & $0 \%$ & $67 \%$ \\
\hline 4 & Infant Mortality Rate 0-1 year per 1000 live births & 50 & $44 \%$ & $94 \%$ \\
\hline 4 & Children under 5 mortality rate per 1000 live births & 50 & $50 \%$ & $94 \%$ \\
\hline 4 & Children 1 year old immunised against measles, percentage & 49 & $67 \%$ & $76 \%$ \\
\hline 5 & $\begin{array}{l}\text { Current contraceptive use among married women, ages 15-49, any } \\
\text { method, percentage }\end{array}$ & 23 & $39 \%$ & $91 \%$ \\
\hline 5 & Births attended by skilled health personnel, percentage & 27 & $56 \%$ & $67 \%$ \\
\hline 6 & Tuberculosis detection rate under DOTS & 43 & $53 \%$ & $72 \%$ \\
\hline 6 & Tuberculosis prevalence rate per 100,000 population & 50 & $46 \%$ & $64 \%$ \\
\hline 6 & Tuberculosis death rate per year per 100,000 population & 50 & $56 \%$ & $46 \%$ \\
\hline
\end{tabular}




\begin{tabular}{|c|c|c|c|c|}
\hline 6 & Tuberculosis incidence rate per year per 100,000 population & 50 & $30 \%$ & $30 \%$ \\
\hline 6 & People Living with HIV 15-49 years old, percentage & 40 & & $38 \%$ \\
\hline 7 & Proportion of the population using improved drinking water sources, total & 46 & $48 \%$ & $83 \%$ \\
\hline 7 & Proportion of the population using improved sanitation facilities, total & 45 & $58 \%$ & $82 \%$ \\
\hline 7 & Slum population as percentage of urban, percentage & 35 & $71 \%$ & $74 \%$ \\
\hline 7 & Terrestrial and marine areas protected to total territorial area, percentage & 46 & $9 \%$ & $54 \%$ \\
\hline 7 & Carbon Dioxide Emissions, metric tons CO2 per capita, (CDIAC) & 47 & $45 \%$ & $40 \%$ \\
\hline 8 & $\begin{array}{l}\text { Debt service as percentage of exports of goods and services and net } \\
\text { income }\end{array}$ & 38 & $47 \%$ & $84 \%$ \\
\hline
\end{tabular}

\subsection{SUB-SAHARAN AFRICA}

The sub-Saharan African results in Table 4 have a pattern similar to that for the LDCs. In 16 of the 24 indicators for which the comparison was made, half or more sub-Saharan African countries experienced accelerated improvement in the second period. In 19 of the 25 indicators, half or more of those countries showed overall improvement since 1990. Again, there are indicators for which our method of analysis provides very different conclusions. For example, "percentage of births attended by skilled health personnel" improved in 67 per cent of sub-Saharan African countries over the course of the entire period, but in less than half was there accelerated improvement in the post-MDG period. In 21 of the 24 indicators studied, our method showed a lower percentage of countries improving than the more standard 1990present method of comparison.

TABLE 4

\section{Sub-Saharan African Countries}

\begin{tabular}{|c|c|c|c|c|}
\hline Goal & Indicator & $\begin{array}{l}\text { Total SSA } \\
\text { countries } \\
\text { available }\end{array}$ & $\begin{array}{l}\text { \% showing } \\
\text { improved } \\
\text { rate in } \\
\text { post-MDG } \\
\text { period }\end{array}$ & $\begin{array}{l}\text { \% showing } \\
\text { overall } \\
\text { improveme } \\
\text { nt first year } \\
\text { to last year }\end{array}$ \\
\hline 1 & Population Below \$1 per day, (PPP), Percentage & 5 & $80 \%$ & $100 \%$ \\
\hline 1 & Growth Rate of GDP per Person Employed, Percentage & 43 & $37 \%$ & $79 \%$ \\
\hline 1 & Employment to Population ratio, both sexes, percentage & 46 & $57 \%$ & $39 \%$ \\
\hline 2 & Total Net Enrolment Ratio in Primary Education, Both Sexes & 31 & $52 \%$ & $87 \%$ \\
\hline 3 & Seats held by women in national parliament, percentage & 47 & $55 \%$ & $85 \%$ \\
\hline 3 & Gender Parity Index in Primary Level Enrolment & 43 & $56 \%$ & $70 \%$ \\
\hline 3 & Gender Parity Index in Secondary Level Enrolment & 37 & $46 \%$ & $81 \%$ \\
\hline 3 & Gender Parity Index in Tertiary Level Enrolment & 23 & $52 \%$ & $83 \%$ \\
\hline 3 & Share of women in wage employment in non-agricultural sector & 6 & $17 \%$ & $100 \%$ \\
\hline 4 & Infant Mortality Rate 0-1 year per 1000 live births & 48 & $54 \%$ & $85 \%$ \\
\hline 4 & Children under 5 mortality rate per 1000 live births & 48 & $63 \%$ & $88 \%$ \\
\hline 4 & Children 1 year old immunised against measles, percentage & 48 & $65 \%$ & $73 \%$ \\
\hline 5 & $\begin{array}{l}\text { Current contraceptive use among married women, ages 15-49, any method, } \\
\text { percentage }\end{array}$ & 22 & $27 \%$ & $91 \%$ \\
\hline 5 & Births attended by skilled health personnel, percentage & 26 & $50 \%$ & $67 \%$ \\
\hline 6 & Tuberculosis detection rate under DOTS & 42 & $57 \%$ & $57 \%$ \\
\hline 6 & Tuberculosis prevalence rate per 100,000 population & 48 & $50 \%$ & $44 \%$ \\
\hline 6 & Tuberculosis death rate per year per 100,000 population & 48 & $56 \%$ & $21 \%$ \\
\hline
\end{tabular}




\begin{tabular}{|c|c|c|c|c|}
\hline 6 & Tuberculosis incidence rate per year per 100,000 population & 47 & $49 \%$ & $13 \%$ \\
\hline 6 & People Living with HIV 15-49 years old, percentage & 45 & & $49 \%$ \\
\hline 7 & Proportion of the population using improved drinking water sources, total & 44 & $39 \%$ & $86 \%$ \\
\hline 7 & Proportion of the population using improved sanitation facilities, total & 44 & $52 \%$ & $82 \%$ \\
\hline 7 & Slum population as percentage of urban, percentage & 38 & $79 \%$ & $79 \%$ \\
\hline 7 & Terrestrial and marine areas protected to total territorial area, percentage & 47 & $11 \%$ & $57 \%$ \\
\hline 7 & Carbon Dioxide Emissions, metric tons $\mathrm{CO} 2$ per capita, (CDIAC) & 48 & $40 \%$ & $44 \%$ \\
\hline 8 & Debt service as percentage of exports of goods and services and net income & 39 & $59 \%$ & $85 \%$ \\
\hline
\end{tabular}

The purpose of this method of analysis, of course, does not only have to be to illustrate that countries or regions are doing "worse". This different perspective can also illustrate positive trends. For example, for total net enrolment in primary education, 87 per cent of subSaharan African countries have improved over the period indicated. Furthermore, in slightly more than half of them have the improvements accelerated in the second period. Much of the official literature focuses on a failure to achieve this MDG, and misses what may be a positive story. The UN MDG report does note that the sub-Saharan Africa's primary school enrolment has increased by 15 per cent since 2000 (United Nations, 2009: 15). The comparison is between absolute levels in 2000 and 2007, but there is no discussion of whether this improvement is a departure from previous regional trends, and no national-level statistics are given. The World Bank predicts that the world will most likely fail to meet the goals involving primary education, citing "sizable shortfalls" in sub-Saharan Africa as one contributing factor to this failure (World Bank, 2009: 19). It is worth remembering here Easterly's point about the unfairness of this "absolute level" goal of 100 per cent enrolment for sub-Saharan Africa, which began at a lower absolute level of enrolment than other regions. Does it make sense to label a region as failing when almost 90 per cent of the countries within it have improved, and more than half have experienced accelerated improvement post-MDG? This goal seems to be one where subSaharan Africa has had some relative success.

\subsection{ASSESSING NON-LINEAR ACCELERATION OF IMPROVEMENT: CHILD MORTALITY}

For some indicators, it is increasingly difficult to accelerate improvement as achievement levels rise. In these cases, the method described above may not be the most suitable means of determining if the MDGs have accelerated progress. To measure year-to-year progress in under-five mortality per 1,000 live births, the United nations Children's Fund (UNICEF) uses a method of calculation known as average annual rate of reduction (AARR). The AARR method reflects the fact that as child mortality rates reach a lower point, the same or greater absolute reduction becomes more difficult to attain. In other words, at a lower level of mortality a similar or even smaller absolute reduction may actually represent a greater percentage reduction (UNICEF, 2008: 153). Hence the AARR is calculated in a way that reflects this fact. In the following section, we have used the AARR to measure whether there has been a post-MDG acceleration of improvement in all countries worldwide, by comparing both 1970-2000 and 1990-2000 rates of improvement with post-2000 rates of improvement. 
This formula is expressed as:

$$
\begin{aligned}
& =\mathrm{IF}\left(D_{\mathrm{FST}}<>99999, \mathrm{ROUND}\left(\left(\left(\mathrm{LN}\left(\mathrm{D}_{\mathrm{MID}} / \mathrm{D}_{\mathrm{FST}}\right)\right) /\left(\mathrm{Y}_{\mathrm{FST}}-\mathrm{Y}_{\text {MID }}\right)\right) * 100,1\right), \text { " }{ }^{\prime \prime}\right) \\
& =I F\left(D_{\text {MID }}<>99999, R O U N D\left(\left(\left(L N\left(D_{L S T} / D_{\text {MID }}\right)\right) /\left(Y_{\text {MID }}-Y_{\text {LST }}\right)\right) * 100,1\right), "{ }^{\prime \prime}\right)
\end{aligned}
$$

where $\mathrm{Y}_{\mathrm{FST}}=$ first year going back to 1970 in first series, 1990 in second, $\mathrm{Y}_{\text {MID }}=2000$, and $\mathrm{Y}_{\text {LST }}$ $=2007, D_{F S T}=$ first year indicator value, $D_{\text {MID }}=$ second year indicator value, $D_{L S T}=$ third year indicator value, and $\mathrm{LN}=$ natural log.

UNICEF has previously used this method to compare time periods for individual countries, as we are proposing to do here. In their State of the World's Children 2009 report, AARR was calculated for every country worldwide from 1970 to 1990, and then from 1990 to 2007, for the purposes of comparison (UNICEF, 2008: 154-157). The change being made here is simply to make the same country-by-country comparison, but using 2000 as the middle year in an attempt to quantify the effect of MDG implementation. UNICEF has already used AARR to provide concrete information on acceleration over the MDG time period (as far as the present authors are aware, it is the only UN body to do so). It reports that there has been a worldwide acceleration in improvement (from a 1.4 per cent to a 2.3 per cent AARR). ${ }^{6}$ This change in trend analysis, however, is not extended to the country level.

Aside from this readily available formula for measurement, under-five mortality was chosen for more detailed examination over a longer period because of its central importance ${ }^{7}$ and because the methods of reporting success or failure for this indicator are especially convoluted. The UN MDG report describes a decline based on a comparison of total under-five deaths worldwide between 1990 and 2007 (United Nations, 2009: 4). At other points in the same report, a comparison of under-five deaths per 1,000 live births worldwide in 1990 and 2007 is cited as evidence of a steady decline (United Nations, 2009: 24). However, the report goes on to remark that in many regions, especially sub-Saharan Africa, there has been "little or no progress" (United Nations, 2009: 25). A graph meant to illustrate worldwide progress includes only three data points, the 1990 level, the 2007 level and the 2015 targets, all at the regionwide level (United Nations, 2009: 24). There is no discussion in the report of any changes in trend at the global, regional or national levels. The World Bank reports that developing countries have made "notable but insufficient progress" towards the MDG of reducing child mortality by two-thirds (World Bank, 2009: 19). The Bank supports this argument by citing an overall reduction in under-five mortality per 1,000 live births in developing countries as a whole from 1990 to 2006. UNICEF has stated on its website that "substantial progress" has been made towards meeting the MDG for under-five mortality. Apart from the abovementioned lone sentence on post-MDG acceleration, however, the UNICEF webpage devoted to under-five mortality statistics continues to focus on 1990-2008 rates of change as a whole, absolute changes during this period, and whether regions are "on track" to meet the MDG. ${ }^{8}$

This paper compares 2000-2007 trends with 1990-2000 trends and also with 1970-2000 trends. The intention was the same, to quantify the extent to which post-MDG trends have improved on historical trends. The UN MDG monitor, the source for all other data used in this paper, only provides data beginning in 1990. For this reason, the World Bank's World Development Indicators (WDI) was used for this section. Using the AARR method and WDI data, two comparisons were made: between the 1970-2000 trends and the 2000-2007 trends, and the 1990-2000 and 2000-2007 trends. Table 6 at the end of the text gives the results. 
Of the 192 countries for which it was possible to calculate 1990-2000 rates, 97 (51 per cent), showed accelerated rates in the 2000-2007 period. This method of calculation results in a better showing than a comparison of only absolute rates of change (see Table 2), as it is designed to do. The 1970-present rate comparisons produce a perhaps more discouraging result. Of 152 countries for which it was possible to calculate 1970-2000 rates, only 67 (44 per cent) showed accelerated improvement over the 1970-2000 rate in the 2000-2007 period. Taken together, these comparisons indicate that there has not been a post-Millennium Declaration improvement over historical trends in under-five mortality reduction in most countries worldwide.

\subsection{METHODOLOGICAL ISSUES AND POSSIBILITIES FOR FUTURE RESEARCH}

One issue with our means of assessing progress is that progress may become steadily more difficult to make in many of these indicators as improvement occurs. As authors such as Rafael Guerreiro Osório have pointed out, assessments of trends in these indicators, which treat the rates of improvement as linear, are inherently problematic. Osório points out that it is unrealistic to expect these indicators to improve at continuous absolute rates, since in many cases it becomes harder to improve at higher levels (Osorio, 2008: 1). Indicators based on percentages have obvious limits. If, for example, primary school enrolment improves from 80 per cent to 95 per cent in the first period, a similar rate of increase is no longer possible in the second. A similar problem with indicators approaching zero, such as infant and child mortality, has already been discussed. We have attempted to control for this issue in two ways. First, we have calculated LDCs and sub-Saharan African countries separately.

The assumption is that these groups started at a lower point on most indicators and thus had more scope for improvement before reaching a point of diminishing possible improvement. This separation also removes developed countries that may already have had very high indicators and therefore little possible room for improvement. The second attempt to address this issue was to use the AARR method of measuring under-five mortality. As explained, this method is designed to control for the fact that greater reductions are more difficult at lower points. The use of logarithm-based calculations such as this one is also one of Osório's recommendations (Osorio, 2008: 1). Both of these methods did produce more positive results than our initial calculations.

Another potential issue is how to control for the effect of global economic conditions during the periods measured. For example, if growth was stagnant, or if there were major economic disruptions or crises in the post-MDG period, this would obviously hinder progress on the indicators. However, a cursory glance at regional and world GDP per capita growth over the periods measured suggests that an absence of faster growth or a stagnation of growth probably does not explain the lack of progress. ${ }^{9}$

It should also be noted that for the bulk of these indicators, the most recent data available was from 2007, before the onset of the food, fuel and financial crises and the global downturn. When this method of measuring progress is used in future, the current economic conditions will have to be taken into account.

Another area for future research is the extent of the progress in countries that are progressing, and the extent of the stagnation or decline in the corresponding countries. Our method registers even a small improvement in the rate of change as acceleration. Moreover, we have not distinguished between stagnation and greater declines. If a large 
proportion of those measured as experiencing accelerated progress have actually done so only slightly, this picture could look much bleaker. Conversely, it is possible that the success stories in this analysis have involved tremendous progress as a result of MDG implementation, while other countries have stagnated.

TABLE 5

Growth of Average Annual GDP Per Capita in Two Periods, \%

\begin{tabular}{lcc}
\hline Region & $\mathbf{1 9 9 1 - 2 0 0 2}$ & $\mathbf{2 0 0 3 - 2 0 0 8}$ \\
\hline World & 1.22 & 2.12 \\
LDCs & 1.10 & 4.47 \\
Sub-Saharan Africa & -0.24 & 3.00 \\
East Asia and Pacific & 6.96 & 8.53 \\
Europe and Central Asia & -0.23 & 6.64 \\
Latin America and Caribbean & 1.13 & 3.58 \\
Middle East and North Africa & 1.68 & 3.12 \\
South Asia & 3.08 & 6.44 \\
\hline
\end{tabular}

There is also a need for institutional analysis. Rough numerical estimations can only give us an indication of whether there has been improvement. To truly and fully measure whether the MDGs have had an impact, an in-depth investigation of institutional and policy changes related to each indicator is also necessary.

A final possibility is that accelerated improvement is about to begin. It is possible that the lag allowed for improved rates is too small, and it is too soon to judge whether the MDGs have had a positive effect. Perhaps, now that there has been institutional change and policies have been implemented, there will be a real acceleration in improvement. Even if this is the case, however, these new rates of improvement will be best judged by a comparison to the preMDG rates.

\section{CONCLUSIONS}

Our analysis shows that there has not been a post-MDG acceleration of improvement in most countries for most indicators, and that many countries have in fact regressed for many of the indicators, suggesting that MDG-related efforts have not met expectations. For under-five mortality, the indicator that was examined in most detail and over a longer period, most countries were not improving on historical trends.

The MDGs are unquestionably worthwhile aspirations and have led to an unprecedented mobilisation of the United Nations system and the international community. The fixation on the MDGs as hard planning targets, however, has distracted from properly measuring the effects of this mobilisation on ending poverty. Global goals set priorities in a normative framework for development policy and benchmarks for evaluating progress. In this framework, the question is whether governments are living up to their commitments and doing more to end poverty. The metric for measuring progress is the rate of progress, not the likelihood of achieving the target. The critical question for implementation is to understand where and why 
progress has accelerated in some countries and not others. Global goals are normative commitments made by world leaders, commitments that can be used in development policy as normative priorities and evaluative benchmarks. Using them as planning targets, particularly at the national level, can be highly misleading.

\section{TABLE 6}

Average Annual Rate of Reduction (AARR), Under-Five Mortality, Comparison of Historical Trends

Totals:

Total Countries for which 1970-2000 Data is available: 152

Percent of those countries where 2000-2007 rate improved on 1970-2000 trend: $44 \%$

Total Countries for which 1990-2000 Data is available: 192

Percent of those countries where 2000-2007 rate improved on 1990-2000 trend: $51 \%$

\begin{tabular}{|c|c|c|c|}
\hline Country & AARR, 1970-2000 & AARR, 1990-2000 & AARR, 2000-2007 \\
\hline Afghanistan & 0.7 & 0.1 & 0.0 \\
\hline Albania & 5.0 & 6.5 & 6.7 \\
\hline Algeria & 5.4 & 4.5 & 2.5 \\
\hline Andorra & n.a & 4.2 & 4.1 \\
\hline Angola & n.a & 3.0 & 2.7 \\
\hline Antigua and Barbuda & n.a & n.a & 4.7 \\
\hline Argentina & 3.9 & 3.0 & 3.7 \\
\hline Armenia & n.a & 4.4 & 5.7 \\
\hline Australia & n.a & 5.1 & 0.7 \\
\hline Austria & 5.3 & 5.1 & 4.4 \\
\hline Azerbaijan & n.a & 3.5 & 8.0 \\
\hline Bahamas & 3.2 & 4.2 & 5.0 \\
\hline Bahrain & 6.4 & 4.6 & 2.3 \\
\hline Bangladesh & 3.2 & 5.1 & 5.8 \\
\hline Barbados & 4.8 & 2.7 & 1.6 \\
\hline Belarus & n.a & 2.9 & 3.9 \\
\hline Belgium & 4.7 & 5.3 & 3.3 \\
\hline Belize & n.a & 4.1 & 1.6 \\
\hline Benin & 1.9 & 2.5 & 2.2 \\
\hline Bhutan & 3.3 & 3.3 & 3.3 \\
\hline Bolivia & 3.5 & 4.0 & 5.4 \\
\hline Bosnia and Herzegovina & 5.2 & 2.6 & 2.6 \\
\hline Botswana & 1.7 & -4.3 & 11.3 \\
\hline Brazil & 4.8 & 6.0 & 5.5 \\
\hline Brunei Darussalam & 7.3 & 2.2 & 0.0 \\
\hline Bulgaria & 2.3 & 1.7 & 4.1 \\
\hline Burkina Faso & 1.3 & 0.8 & -0.1 \\
\hline Burundi & 0.6 & 0.3 & 0.3 \\
\hline Cambodia & n.a & 1.1 & 2.3 \\
\hline Cameroon & 1.2 & -0.8 & 0.3 \\
\hline
\end{tabular}




\begin{tabular}{|c|c|c|c|}
\hline Canada & 4.3 & 2.9 & 0.7 \\
\hline Cape Verde & n.a & 3.6 & 3.8 \\
\hline Central African Republic & 0.7 & -0.8 & 1.1 \\
\hline Chad & n.a & -0.2 & -0.3 \\
\hline Chile & 7.4 & 6.7 & 2.4 \\
\hline China & 3.9 & 2.2 & 7.3 \\
\hline Colombia & 4.6 & 2.9 & 3.6 \\
\hline Comoros & 3.1 & 3.6 & 3.5 \\
\hline Congo & 0.7 & -1.1 & -1.1 \\
\hline Cook Islands & n.a & 2.9 & 4.1 \\
\hline Costa Rica & 5.9 & 2.5 & 2.8 \\
\hline Cote d'Ivoire & 1.8 & 1.0 & 1.0 \\
\hline Croatia & 5.4 & 4.3 & 5.3 \\
\hline Cuba & 5.2 & 3.7 & 4.8 \\
\hline Cyprus & 5.2 & 4.9 & 5.3 \\
\hline Czech Republic & 5.2 & 9.6 & 3.5 \\
\hline Democratic Republic of the Congo & 0.9 & 1.2 & 1.4 \\
\hline Denmark & 3.5 & 4.1 & 4.4 \\
\hline Djibouti & n.a & 1.7 & 2.0 \\
\hline Dominica & 4.5 & 1.6 & 4.4 \\
\hline Dominican Republic & 4.2 & 5.8 & -0.3 \\
\hline Ecuador & 4.9 & 5.8 & 5.2 \\
\hline Egypt & 5.1 & 6.1 & 4.8 \\
\hline El Salvador & 5.1 & 5.4 & 5.5 \\
\hline Equatorial Guinea & n.a & -1.6 & -0.4 \\
\hline Eritrea & 3.0 & 4.2 & 4.6 \\
\hline Estonia & 2.1 & 4.7 & 9.5 \\
\hline Ethiopia & 1.6 & 3.1 & 3.4 \\
\hline Fiji & n.a & 1.8 & 0.5 \\
\hline Finland & 4.6 & 5.6 & 1.9 \\
\hline France & 4.5 & 4.9 & 3.5 \\
\hline Gabon & n.a & 0.1 & 0.0 \\
\hline Gambia & 2.9 & 1.5 & 2.7 \\
\hline Georgia & n.a & 3.0 & 2.0 \\
\hline Germany & 5.5 & 5.9 & 1.8 \\
\hline Ghana & 1.7 & 0.7 & -0.5 \\
\hline Greece & 5.3 & 4.9 & 6.6 \\
\hline Grenada & n.a & 3.5 & 4.5 \\
\hline Guatemala & 3.8 & 4.4 & 4.4 \\
\hline Guinea & 1.9 & 2.2 & 3.0 \\
\hline Guinea-Bissau & n.a & 1.0 & 1.4 \\
\hline Guyana & n.a & 2.3 & 2.2 \\
\hline Haiti & 2.4 & 3.3 & 5.2 \\
\hline Honduras & 4.9 & 3.8 & 7.1 \\
\hline
\end{tabular}




\begin{tabular}{|c|c|c|c|}
\hline Hungary & 4.8 & 6.1 & 4.3 \\
\hline Iceland & 4.8 & 5.8 & 5.6 \\
\hline India & 2.5 & 2.5 & 3.4 \\
\hline Indonesia & 4.3 & 6.4 & 6.2 \\
\hline Iran & 4.9 & 4.9 & 4.2 \\
\hline Iraq & 3.2 & 1.1 & 1.0 \\
\hline Ireland & 4.5 & 2.5 & 7.3 \\
\hline Israel & 4.9 & 5.3 & 4.4 \\
\hline Italy & 6.3 & 6.3 & 4.3 \\
\hline Jamaica & 2.2 & 0.4 & 0.4 \\
\hline Japan & 4.6 & 3.5 & 3.6 \\
\hline Jordan & 4.2 & 2.9 & 3.0 \\
\hline Kazakhstan & 2.3 & 3.1 & 4.8 \\
\hline Kenya & 1.0 & -1.9 & -0.5 \\
\hline Kiribati & n.a & 2.3 & 1.5 \\
\hline Korea, DRC & 0.8 & 0.0 & 0.0 \\
\hline Korea, Republic of & 7.7 & 5.1 & 1.6 \\
\hline Kuwait & 5.0 & 1.4 & 2.5 \\
\hline Kyrgyzstan & n.a & 3.9 & 3.9 \\
\hline Lao PDR & 2.6 & 4.8 & 5.2 \\
\hline Latvia & 1.1 & 1.5 & 7.6 \\
\hline Lebanon & 1.8 & 1.6 & 1.0 \\
\hline Lesotho & 1.6 & -0.4 & 3.5 \\
\hline Liberia & 1.8 & 2.2 & 3.0 \\
\hline Libyan Arab Jamahiriya & 6.6 & 6.2 & 3.0 \\
\hline Liechtenstein & n.a & 5.1 & 12.5 \\
\hline Lithuania & 2.5 & 4.0 & 3.5 \\
\hline Luxembourg & 5.5 & 5.9 & 8.3 \\
\hline Madagascar & 0.9 & 2.0 & 2.9 \\
\hline Malawi & 2.3 & 2.1 & 6.1 \\
\hline Malaysia & 5.4 & 4.5 & 3.2 \\
\hline Maldives & n.a & 7.1 & 8.5 \\
\hline Mali & 1.8 & 1.4 & 1.5 \\
\hline Malta & 4.5 & 4.3 & 4.6 \\
\hline Marshall Islands & n.a & 3.0 & 3.3 \\
\hline Mauritania & 2.2 & 0.6 & 0.4 \\
\hline Mauritius & 5.0 & 2.4 & 3.3 \\
\hline Mexico & 3.5 & 3.1 & 1.5 \\
\hline Micronesia & n.a & 2.1 & 2.1 \\
\hline Monaco & n.a & 4.8 & 4.2 \\
\hline Mongolia & n.a & 4.4 & 5.4 \\
\hline Montenegro & n.a & 1.6 & 3.8 \\
\hline Morocco & 4.1 & 5.0 & 6.4 \\
\hline Mozambique & 1.4 & 0.8 & 1.3 \\
\hline
\end{tabular}




\begin{tabular}{|c|c|c|c|}
\hline Myanmar & 1.6 & 1.7 & 0.9 \\
\hline Namibia & 0.8 & -1.4 & 5.5 \\
\hline Nauru & n.a & 0.0 & 0.0 \\
\hline Nepal & 3.4 & 5.1 & 6.4 \\
\hline Netherlands & 3.1 & 3.5 & 2.5 \\
\hline New Zealand & 3.1 & 3.2 & 4.6 \\
\hline Nicaragua & 4.5 & 4.6 & 3.1 \\
\hline Niger & 1.1 & 2.8 & 3.8 \\
\hline Nigeria & 0.8 & 1.1 & 1.3 \\
\hline Norway & 3.9 & 5.8 & 4.1 \\
\hline Occupied Palestinian Territory & 8.7 & 7.8 & 2.7 \\
\hline Oman & n.a & 2.7 & 0.9 \\
\hline Pakistan & 1.8 & 2.2 & 2.3 \\
\hline Palau & n.a & 3.9 & 4.4 \\
\hline Panama & 3.3 & 2.9 & 1.7 \\
\hline Papua New Guinea & 2.4 & 2.2 & 2.2 \\
\hline Paraguay & 2.7 & 2.1 & 2.1 \\
\hline Peru & 4.9 & 6.7 & 9.9 \\
\hline Philippines & 3.0 & 5.2 & 3.7 \\
\hline Poland & 4.3 & 5.9 & 4.9 \\
\hline Portugal & 7.4 & 7.1 & 9.1 \\
\hline Qatar & 3.3 & 3.2 & 3.2 \\
\hline Republic of Moldova & 3.3 & 4.2 & 4.1 \\
\hline Romania & 2.8 & 3.4 & 6.0 \\
\hline Russian Federation & 1.7 & 1.2 & 7.1 \\
\hline Rwanda & 0.6 & 0.3 & 0.6 \\
\hline Saint Kitts and Nevis & n.a & 3.6 & 4.7 \\
\hline Saint Lucia & 4.7 & 2.6 & -1.8 \\
\hline Saint Vincent and the Grenadines & 3.6 & -0.7 & 3.3 \\
\hline Samoa & 3.6 & 3.9 & 3.2 \\
\hline San Marino & n.a & 6.7 & 9.3 \\
\hline Sao Tome and Principe & 0.1 & 0.1 & 0.2 \\
\hline Saudi Arabia & 6.2 & 4.2 & 2.2 \\
\hline Senegal & 2.4 & 1.2 & 2.2 \\
\hline Serbia & n.a & n.a & 6.9 \\
\hline Seychelles & 4.7 & 2.7 & 1.8 \\
\hline Sierra Leone & 1.0 & 0.5 & 0.7 \\
\hline Singapore & 6.3 & 6.7 & 5.9 \\
\hline Slovakia & 3.8 & 4.2 & 3.1 \\
\hline Slovenia & 5.6 & 6.6 & 4.6 \\
\hline Solomon Islands & n.a & 3.2 & 3.2 \\
\hline Somalia & n.a & 2.1 & 2.1 \\
\hline South Africa & 1.4 & -1.5 & 3.3 \\
\hline Spain & 5.8 & 5.4 & 3.5 \\
\hline
\end{tabular}




\begin{tabular}{|c|c|c|c|}
\hline Sri Lanka & 4.9 & 3.4 & 1.6 \\
\hline Sudan & 1.3 & 0.8 & 0.8 \\
\hline Suriname & n.a & 2.9 & 4.1 \\
\hline Swaziland & 1.4 & -3.2 & 5.4 \\
\hline Sweden & 4.0 & 5.7 & 3.2 \\
\hline Switzerland & 3.8 & 3.8 & 2.4 \\
\hline Syrian Arab Republic & 5.8 & 5.1 & 3.9 \\
\hline Tajikistan & 1.3 & 2.2 & 4.8 \\
\hline Thailand & 7.0 & 8.9 & 8.5 \\
\hline The FYR of Macedonia & 6.7 & 8.6 & -0.5 \\
\hline Timor-Leste & n.a & 3.5 & 4.1 \\
\hline Togo & 2.0 & 2.1 & 2.8 \\
\hline Tonga & 2.1 & 1.9 & 1.9 \\
\hline Trinidad and Tobago & 1.5 & 0.0 & -0.4 \\
\hline Tunisia & 6.2 & 5.2 & 5.4 \\
\hline Turkey & 5.1 & 6.2 & 9.3 \\
\hline Turkmenistan & n.a & 3.3 & 5.0 \\
\hline Tuvalu & n.a & 2.3 & 1.8 \\
\hline Uganda & 0.9 & 1.6 & 1.9 \\
\hline Ukraine & 1.6 & 1.0 & -1.0 \\
\hline United Arab Emirates & 7.0 & 3.8 & 3.8 \\
\hline United Kingdom & 3.6 & 3.1 & 2.7 \\
\hline United Republic of Tanzania & 1.4 & 0.9 & 3.1 \\
\hline United States & 3.6 & 3.5 & 0.7 \\
\hline Uruguay & 4.2 & 3.9 & 2.7 \\
\hline Uzbekistan & n.a & 1.7 & 6.0 \\
\hline Vanuatu & 3.9 & 2.6 & 4.8 \\
\hline Venezuela & 3.2 & 3.0 & 3.1 \\
\hline Viet Nam & 3.5 & 6.2 & 10.0 \\
\hline Yemen & 3.8 & 2.6 & 4.3 \\
\hline Zambia & 0.0 & -0.9 & 0.7 \\
\hline Zimbabwe & 0.2 & -2.4 & 4.3 \\
\hline
\end{tabular}


GRAPH

Number of Countries Showing Accelerated Improvement per Indicator

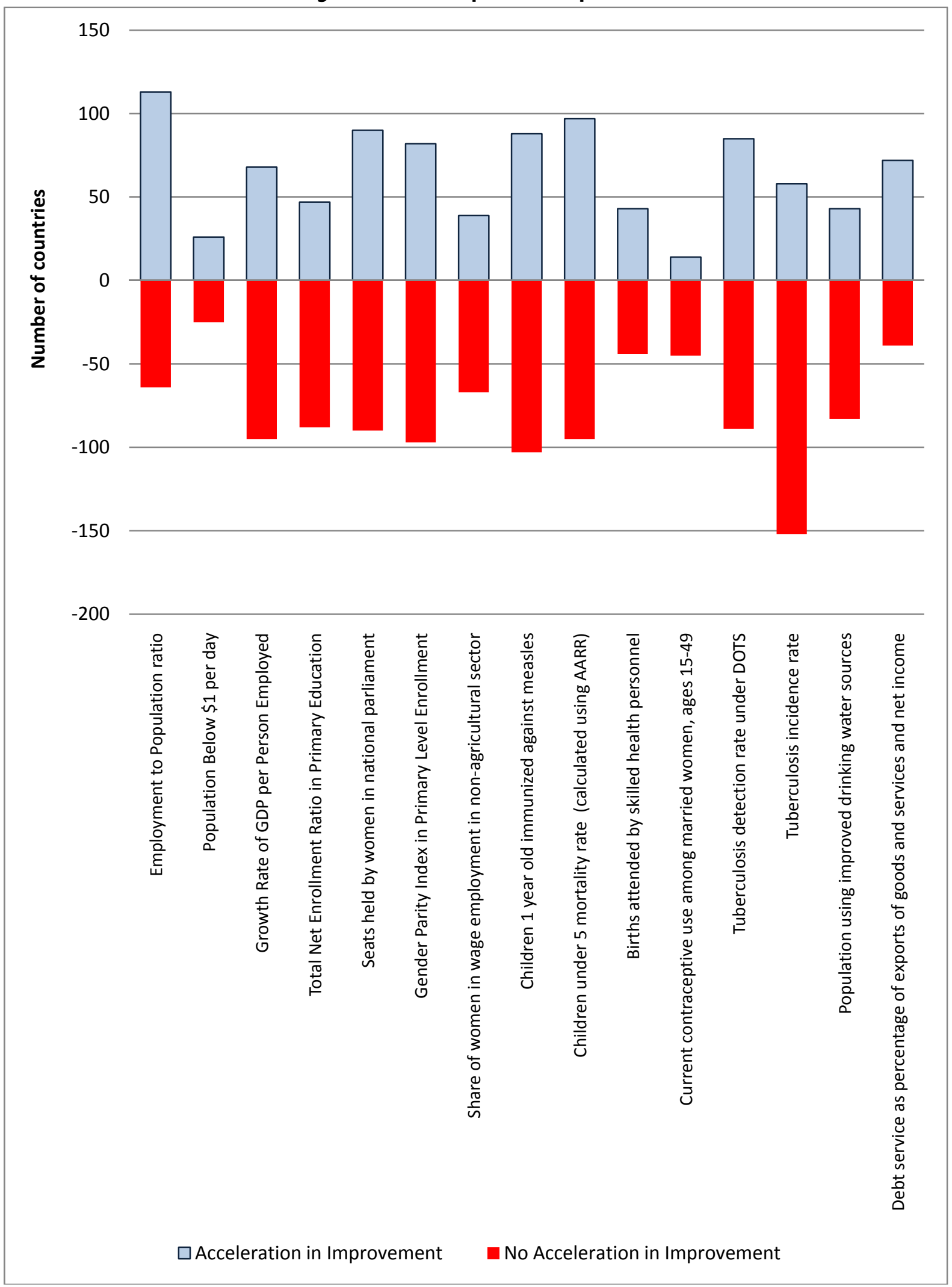




\section{REFERENCES}

African Development Bank (2009). Assessing Progress in Africa Towards the Millennium Development Goals. MDG Report 2009. United Nations Economic Commission for Africa, African Union Commission, African Development Bank.

Asian Development Bank (2007). The Millennium Development Goals: Progress in Asia and the Pacific 2007. Bangkok, United Nations Economic and Social Commission for Asia and Pacific, Asian Development Bank, United Nations Development Programme.

Clemens, M. (2007). 'The Trouble with the MDGs: Confronting Expectations of Aid and Development Success', World Development 35 (5), 735-751.

Easterly, W. (2009a). 'How the Millennium Development Goals are Unfair to Africa', World Development 37 (1), 26-35.

Easterly, W. (2009b). 'The Tragedy of the Millennium Development Goals', Aidwatch website, $<$ http://aidwatchers.com/2009/07/the-tragedy-of-the-millennium-development-goals/>, accessed 25 January 2010.

Fukuda-Parr, S. (2004). 'Millennium Development Goals: Why They Matter', Global Governance 10 (4), 395-402.

Osório, R. G. (2008). 'Can we Accurately Project MDG Indicators?' IPC-IG One Pager 68. Brasilia, International Policy Centre for Inclusive Growth.

Saith, A. (2006). 'From Universal Values to Millennium Development Goals: Lost in Translation', Development and Change 37 (6), 1167-1199.

Social Watch (2005). 'Social Watch Asia Regional Meeting in Cambodia; Angkor Wat Declaration', Social Watch website, <http://www.socialwatch.org/node/9495>, accessed 28 February 2010.

Tabatabai, H. (2007). 'MDG Targets: Misunderstood or Misconceived?' IPC-IG One Pager 33. Brasilia, International Policy Centre for Inclusive Growth.

UNICEF (2008). The State of the World's Children 2009. New York, UNICEF.

UNICEF (2009). 'Child Survival and Health', Childinfo website, $<$ http://www.childinfo.org/mortality.html $>$, accessed 28 February 2010.

United Nations (n.d.). 'We Can End Poverty 2015: Millennium Development Goals', UN website, <http://www.un.org/millenniumgoals/bkgd.shtml>, accessed 7 March 2010.

United Nations (2005). In Larger freedom: Towards Development, Security and Human Rights for All. Report of the Secretary General. New York, United Nations.

United Nations (2006). 'About the MDGS: What They Are', UN Millennium Project website, <http://www.unmillenniumproject.org/goals/index.htm>, accessed 7 March 2010.

United Nations (2009). The Millennium Development Goals Report 2009. New York, United Nations Department of Economic and Social Affairs.

United Nations Statistics Division (2010). 'Millennium Development Goals Indicators', UN Statistics Division website, <http://mdgs.un.org/unsd/mdg/Data.aspx>.

Vandemoortele, J. (2007). 'MDGs: Misunderstood Targets?' IPC-IG One Pager 28. Brasilia, International Policy Centre for Inclusive Growth.

World Bank (2009). Global Monitoring Report 2009. Washington, DC, World Bank.. 


\section{NOTES}

1. Global goals can be used in global and national development strategies in three ways: as priorities in a normative framework, as benchmarks in evaluating progress, or as planning targets.

2. In addition to excluding indicators with insufficient information, several other indicators were not included in the final tallies. Many Goal 8 indicators, such as untied official development assistance (ODA) or ODA to social services, are "input", rather than outcome-related. Because the purpose of the paper is to provide a methodology for measuring the impact of the MDGs, including the impact of increased aid, such input indicators were not included. Also excluded were three Goal 8 technology-related indicators: telephone lines, internet users and mobile telephone users per 100 population. It can be assumed that these indicators consistently improved for virtually every country during the period and that this phenomenon is unrelated to MDG implementation. For example, 201 of 202 countries for which data were available saw an increase in the number of internet users per 100 population from 1990 to the most recent date available (North Korea was the sole exception). This does not seem relevant in determining the success of the MDGs. Finally, there are four separate indicators measuring carbon emissions: the United Nations Framework Convention on Climate Change (UNFCCC) measure of emissions in total metric tons; UNFCCC emissions per capita; the Carbon Dioxide Information Analysis Center (CDIAC) measure of total emissions in metric tons; and CDIAC emissions per capita. To avoid skewing the results by including four indicators measuring essentially the same variable, it was decided to include only one carbon emission-related indicator, the CDIAC measure of emissions per capita (for which data was available for significantly more countries).

3. United Nations Statistics Division, Millennium Development Goals Indicators: http://mdgs.un.org/unsd/mdg/Data.aspx.

4. In many cases, it is possible that the indicator data improved from start to finish, but improved at a lower rate in the second period. This would not be shown as an improvement in the second period. Conversely, there were also a few cases in which the indicator data declined throughout, but declined at a lower rate in the second period. This would be shown as improvement in the second period using this method.

5. For a more detailed explanation of the projection calculations, see Asian Development Bank, 2007: 52.

6. UNICEF, Statistics by Area/Child Survival and Health: http://www.childinfo.org/mortality.html.

7. The indicator is important for both intrinsic and instrumental reasons. Survival is clearly of the ultimate intrinsic value for all human beings. The extent to which a society is able to assure the survival of children is of central importance in evaluating social arrangements. It reflects a number of circumstances, such as accessibility of clean water, sanitation facilities, the education of women, maternal-child health support, provision of primary healthcare facilities, provisioning for food security and others. Child survival, reflecting more broadly the health of children, is instrumentally important for other development objectives such as building human capital and facilitating the demographic transition.

8. UNICEF, Statistics by Area/Child Survival and Health: http://www.childinfo.org/mortality.html.

9. Source of GDP per capita data is the World Bank's World Development Indicators. These numbers represent a simple average of the aggregate annual percent growth in per capita GDP for the regions and years indicated. 


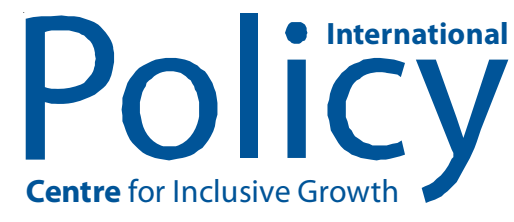

International Policy Centre for Inclusive Growth (IPC - IG)

Poverty Practice, Bureau for Development Policy, UNDP

Esplanada dos Ministérios, Bloco O, $7^{\circ}$ andar

70052-900 Brasilia, DF - Brazil

Telephone: +55 6121055000

E-mail: ipc@ipc-undp.org • URL: www.ipc-undp.org 